\title{
The environmental impact of the Puyehue-Cordon Caulle 2011 volcanic eruption on Buenos Aires
}

\author{
G. B. Raga ${ }^{1}$, D. Baumgardner ${ }^{2}$, A. G. Ulke ${ }^{3,4}$, M. Torres Brizuela ${ }^{3}$, and B. Kucienska ${ }^{1}$ \\ ${ }^{1}$ Centro de Ciencias de la Atmósfera, Universidad Nacional Autónoma de México, DF, México \\ ${ }^{2}$ Droplet Measurement Technologies, Boulder, CO, USA \\ ${ }^{3}$ Departamento de Ciencias de la Atmósfera y los Océanos, Facultad de Ciencias Exactas y Naturales, \\ Universidad de Buenos Aires, Buenos Aires, Argentina \\ ${ }^{4}$ Unidad Mixta Internacional (UMI) - Instituto Franco Argentino sobre Estudios de Clima y sus Impactos (IFAECI)/CNRS, \\ Buenos Aires, Argentina
}

Correspondence to: G. B. Raga (graciela.raga@gmail.com)

Received: 4 April 2013 - Published in Nat. Hazards Earth Syst. Sci. Discuss.: 24 April 2013

Revised: 30 July 2013 - Accepted: 5 August 2013 - Published: 23 September 2013

\begin{abstract}
On 4 June 2011, the volcanic complex PuyehueCordon Caulle located in the Chilean Andes erupted, producing a plume of gases and particles that eventually circled the Southern Hemisphere, disrupting air travel and depositing ash in large quantities. On eight occasions, the plume passed over the city of Buenos Aires, Argentina, leading local authorities to close the two international airports.

The eruption occurred during an on-going field campaign when measurements of the properties of atmospheric aerosol particles were being made in Buenos Aires as part of a yearlong study of the concentration and optical properties of aerosol at one site in the city. The suite of instruments deployed in Buenos Aires were not tailored to measurements of volcanic ash, but were designed to characterize urban conditions. Nevertheless, these measurements were analysed for periods when vertical profiles of aerosol backscatter, made with a ceilometer, clearly showed the presence of the volcano plume over the research site and resulted in airport closure.

Aerosol optical thickness derived from AERONET, MODIS and a ceilometer at our research site, all show enhanced values clearly indicating that the three platforms identified the volcanic plume simultaneously. However, a quantitative comparison of the different estimates proves difficult, suggesting large spatial and temporal variability of the plume.
\end{abstract}

Our results indicate that the number concentration of condensation nuclei $(\mathrm{CN})$, the mass concentration of particlebound polycyclic aromatic hydrocarbons (PPAH) and the light absorption coefficient exceeded the average background values by more than one standard deviation during the events of volcanic plume. The anomalous concentrations of $\mathrm{CN}$ suggest new particle formation, presumably from the conversion of $\mathrm{SO}_{2}$, while the anomalous concentrations of PPAH may come from the uptake of PAHs on the plume particles or from chemical reactions on the surface of plume particles. The anomalous absorption coefficients indicate that plume particles may contain certain compounds that can absorb radiation at $550 \mathrm{~nm}$. Another possible explanation consistent with the observations is the scavenging of black carbon from urban sources as the plume descends through the boundary layer to the surface. In addition, the volcanic plume influenced the local meteorology resulting in a decrease of the temperature when compared to the average temperature during days with no plume present.

\section{Introduction}

The volcanic complex Puyehue-Cordon Caulle in the Chilean southern Andes erupted at 14:45 local time (LT) on 4 June 2011 (SERNAGEOMIN, 2011) from a new vent ("We Pillán" located $7 \mathrm{~km} \mathrm{NNW}$ of the crater of the Puyehue volcano, Collini et al., 2013) of the Cordon Caulle complex, located in the southern Andes volcanic zone (SAVZ) at $40.58^{\circ} \mathrm{S}$ and $72.13^{\circ} \mathrm{W}$, and $2240 \mathrm{~m}$ above mean sea level (a.m.s.l.). The sub-plinian eruption 
produced a large plume of gas and ash particles that reached $10 \mathrm{~km}$ above crater rim level and that eventually circled the Southern Hemisphere disrupting air travel on several continents. By 13 June the plume had reached New Zealand, extending in the vertical between 6 and $11 \mathrm{~km}$ above sea level (http://earthobservatory.nasa.gov/NaturalHazards/view. php?id=50985). The intensity of the eruptive process was not constant in time, resulting in large variability of the height of the top of the plume, which was monitored by cameras located near the eruption. Large quantities of ash fell in the nearby regions until the end of July, causing major problems in villages and cities of the Patagonian Andes and permanent closure of airports. Thousands of sheep eventually died of starvation due to the heavy layer of ash that covered and killed the vegetation that they consume. This complex had previously erupted $51 \mathrm{yr}$ earlier, on 24 May 1960, following the $M_{\mathrm{w}} 9.5$ great Chilean earthquake about $240 \mathrm{~km}$ to the west (Lara et al., 2004). Gerlach et al. (1988) and Lara et al. (2006) presented a summary of recent eruptions of this volcanic complex, while Singer et al. (2008) presented its long-term history.

A couple of days after the 4 June 2011 eruption, the ash was carried approximately $1400 \mathrm{~km}$ to the NE, reaching Buenos Aires $\left(34.54^{\circ} \mathrm{S}, 58.44^{\circ} \mathrm{W}\right)$ and resulting in major air traffic disruption at the two international airports that service the city: Aeroparque (AEP) and Ezeiza (EZE). The vent continued producing emissions hazardous to flight operations until December 2011. The Volcanic Ash Advisory Center (VAAC) for South America, hosted by the National Weather Service of Argentina, is responsible for issuing warnings based upon an ash dispersion model. This information is used by the National Civil Aviation Administration to advise airlines on the atmospheric conditions related to the ash and is the agency with authority to close down aircraft operations at the airports. However, each airline and pilot evaluated the situation and made the final decision to operate. Collini et al. (2013) performed non-operational simulations of the volcanic ash plume trajectory by combining the Weather and Research Forecasting model in conjunction with the dispersion model FALL3D (Folch et al., 2009) and concluded that this combination of models provided reasonable results for the forecast of plume trajectory and ash deposits.

Table 1 shows the dates of the eight periods during which ash affected the air space over Buenos Aires during June and July forcing both airports to close for at least one day. Also given in this table is our assessment, based on measurements with a ceilometer (discussed below) of whether the volcanic plume was present. Entries listed as "possibly" indicate times when ash appeared to be present but normal flight operations were underway. There was at least one period when flight operations were cancelled but our analysis of the ceilometer data indicated no volcanic plume present. More than 5000 flights by the three largest airlines operating from AEP had to be cancelled and/or rescheduled during the period of two months considered in this study. Visible images from MODIS on Terra and Aqua with the volcanic plume covering central Argentina and reaching Buenos Aires, have been featured in the NASA website and can be found in http://www.nasa.gov/topics/ earth/features/20110606-volcano.html and http://www.nasa. gov/topics/earth/features/20110615-volcano.html.

Following the Eyjafjallajökull volcanic eruption in Iceland in April-May 2010, several European research groups made ground-based measurements of the volcanic plume properties, using equipment similar to the one installed in Buenos Aires. In Augsburg, Germany, Pitz et al. (2011) measured the size distribution of aerosol particles in April 2010 reporting that the mass concentration of $\mathrm{PM}_{10}$ (particles with an aerodynamic diameter less than $10 \mu \mathrm{m}$ ) exceeded the daily limit of $50 \mu \mathrm{g} \mathrm{m}^{-3}$. Using positive matrix factorization, they showed that this increase was a result of ash transported from the volcano. A little farther to the south, in the Alpine region of Germany, during this same time period, on 19 and 20 April, $\mathrm{PM}_{10}$ was reported to exceed the daily threshold value at nearly all monitoring stations of the northern Alpine foothills as well as at mountain and valley stations in the northern Alps (Schäfer et al., 2011). The entrainment of the volcanic plume mainly affected the concentrations of coarse particles $(>1 \mu \mathrm{m})-$ interpreted as volcanic ash - and ultrafine particles $(<100 \mathrm{~nm})$ presumably produced from chemical processes that converted the sulfur dioxide in the plume to new particles. In this same region, Flentje et al. (2010) measured the volcanic plume with a ceilometer, ozonesondes and ground-based measurements that they could connect with the presence of the ash. In southern France, Hervo et al. (2012) made lidar and ground-based measurements while the plume was detected over the Puy de Dôme and found a clear augmentation of the normal background aerosol properties. Finally, even farther to the SE, Bukowiecki et al. (2011) made measurements of the properties of the volcanic plume at the high altitude research station Jungfraujoch (3580 m a.s.l.) as the ash layer was advected further south.

The eruption on the Cordon Caulle complex took place while a suite of instruments installed in Buenos Aires were making measurements in a year-long study to characterize the concentration and optical properties of aerosol particles in the city. The project constituted the first such long-term campaign in the city. The objective of our study is to analyse particle characteristics at the surface measured on days when the volcanic plume was above the research site in Buenos Aires (the specific days analysed: 7, 8, 13 and 14 June and 1, 2, 7 and 8 July 2011). The next section discusses our measurement system and analysis methodology. Section 3 presents the results of the selected case studies with descriptions of the meteorological conditions, the vertical backscattering profiles and the surface measurements. A discussion of the results is given in Sect. 4 and the conclusions are summarized in the final section. 
Table 1. List of all the eruptive episodes that led to shut downs of airport operations at Aeroparque (AEP) and Ezeiza (EZE) airports during the months of June and July 2011.

\begin{tabular}{|c|c|c|c|c|}
\hline $\begin{array}{l}\text { Julian } \\
\text { day }\end{array}$ & $\begin{array}{l}\text { Calendar } \\
\text { day }\end{array}$ & $\begin{array}{l}\text { Episode } \\
\text { No. }\end{array}$ & $\begin{array}{l}\text { Inferred by } \\
\text { ceilometer data }\end{array}$ & $\begin{array}{l}\text { Listed in publication } \\
\text { "Lima Victor } \mathrm{N}^{\circ} 35 "\end{array}$ \\
\hline 157 & 6 June & 1 & Yes & Flight operations at EZE cancelled at night \\
\hline 158 & 7 June & 1 & Yes & $\begin{array}{l}\text { No flight operations at AEP and EZE during the morning. EZE re-opened at } \\
\text { noon, AEP at } 4 \text { p.m. LT }\end{array}$ \\
\hline 159 & 8 June & 1 & Yes & Normal operations at AEP and EZE \\
\hline 160 & 9 June & 2 & Possibly (fog?) & No flight operations AEP nor EZE \\
\hline 161 & 10 June & 2 & Yes & Operations resume at AEP and EZE at 7 p.m. LT \\
\hline 162 & 11 June & 2 & No & Normal operations at AEP and EZE \\
\hline 163 & 12 June & 2 & Possibly & Normal operations at AEP and EZE \\
\hline 164 & 13 June & 3 & Yes & No flight operations AEP nor EZE \\
\hline 165 & 14 June & 3 & Yes & Flight operations at EZE resume at night \\
\hline 166 & 15 June & 3 & No-rain & Flight operations at AEP resume in the morning \\
\hline 172 & 21 June & 3 & No & Normal operations at AEP and EZE \\
\hline 173 & 22 June & 3 & Possibly & Normal operations at AEP and EZE \\
\hline 175 & 24 June & 4 & Yes & $\begin{array}{l}\text { No flight operations AEP nor EZE. Operations at AEP resume at } 5.30 \text { p.m. LT. } \\
\text { EZE resumes at night }\end{array}$ \\
\hline 176 & 25 June & 4 & Yes & Normal operations at AEP and EZE in the morning \\
\hline 182 & 1 July & 5 & Yes & At 2 p.m. LT both AEP and EZE stop operations. \\
\hline 183 & 2 July & 5 & Yes & Operations resume after 8 a.m. LT \\
\hline 184 & 3 July & 5 & No & Normal operations at AEP and EZE \\
\hline 188 & 7 July & 6 & Yes & Operations at AEP and EZE stop at 6 p.m. LT \\
\hline 189 & 8 July & 6 & Yes & Normal operations resume in the afternoon \\
\hline 191 & 10 July & 7 & No & No operations from around local noon at AEP and EZE \\
\hline 192 & 11 July & 7 & No & Operations resume after 11 a.m. LT \\
\hline 207 & 26 July & 8 & Yes & Operations stop at AEP and EZE around noon \\
\hline 208 & 27 July & 8 & Yes & Operations resume mid-morning at EZE and mid-afternoon at AEP \\
\hline
\end{tabular}

\section{Methodology}

\subsection{Instrumentation}

A suite of instruments was installed on the roof of one of the buildings of the Facultad de Ciencias Exactas y Naturales, Universidad de Buenos Aires (FCEN, UBA) located at $34.54^{\circ} \mathrm{S}, 58.44^{\circ} \mathrm{W}$ and at an altitude of approximately $30 \mathrm{~m}$ above sea level, as part of a year-long campaign to characterize the concentration and optical properties of aerosol particles. The measurements included the number concentration of condensation nuclei $(\mathrm{CN})$ larger than approximately $20 \mathrm{~nm}$, the mass concentration of particle-bound polycyclic aromatic hydrocarbons (PPAH), the scattering (Bscat) and absorption (Babs) coefficients at $530 \mathrm{~nm}$ and the vertical profiles of backscattered light from aerosols at a wavelength of $910 \mathrm{~nm}$. In addition, a weather station recorded the meteorological state of the atmosphere (see Table 2 for detailed instrument characteristics). Measurements began in April 2011 and continued until December. All the data were averaged into ten-minute intervals for the analysis discussed below.

Additional information on aerosol optical properties was obtained from the AERONET sun-photometer (Holben et al., 1998), maintained and operated by researchers at CEILAP
(Centro de Investigaciones en Láseres y Aplicaciones) and located approximately four kilometers west of the UBA measurement site. While the AERONET sun-photometer measures at multiple wavelengths, only the aerosol optical thickness (AOT) at $500 \mathrm{~nm}$ was selected for analysis. This wavelength is closest to the $530 \mathrm{~nm}$ wavelength used by the PSAP and nephelometer and the $550 \mathrm{~nm}$ wavelength used by the Moderate Resolution Imaging Spectroradiometer (MODIS) that is carried on the Aqua (Parkinson, 2003) and Terra satellites and whose data we also used to evaluate the AOT. Finally, note that the AEP airport is located three kilometres south of the research site, while the EZE airport is $31 \mathrm{~km}$ to the SW.

The meteorological conditions during the event were studied using the reanalysis dataset from the National Centers of Environmental Prediction, National Center for Atmospheric Research (Kalnay et al., 1996).

\subsection{Analysis strategy}

The ceilometer records a range-corrected intensity of light that is backscattered from an ensemble of aerosols in intervals of $20 \mathrm{~m}$ up to $7 \mathrm{~km}$. Hence, the CL-31 ceilometer functions as a light detection and ranging (LIDAR) sensor 
Table 2. Description of instrumentation deployed at the research site at the Facultad de Ciencias Exactas y Naturales, Universidad de Buenos Aires (FCEN, UBA). The acronym UNAM corresponds to Universidad Nacional Autónoma de México.

\begin{tabular}{|c|c|c|c|c|c|}
\hline Parameter & Instrument & Institute & Detection limit & Accuracy & Frequency \\
\hline $\begin{array}{l}\text { Temperature, } \\
\text { RH, } \\
\text { pressure }\end{array}$ & $\begin{array}{l}\text { Davis Inc. } \\
\text { Weather Station }\end{array}$ & UBA & $\begin{array}{l}-50^{\circ} \text { to }+50^{\circ} \\
0 \text { to } 100 \% \\
100 \text { to } 1024\end{array}$ & $\begin{array}{l} \pm 1^{\circ} \\
\pm 5 \% \\
\pm 1 \mathrm{mb}\end{array}$ & $1 \mathrm{~Hz}$ \\
\hline $\begin{array}{l}\text { Horizontal } \\
\text { winds }\end{array}$ & $\begin{array}{l}\text { Davis Inc. } \\
\text { Weather Station }\end{array}$ & UNAM & 0 to $50 \mathrm{~m} \mathrm{~s}^{-1}$ & & $1 \mathrm{~Hz}$ \\
\hline $\begin{array}{l}\text { Condensation } \\
\text { nuclei }\end{array}$ & TSI CPC 3010 & UNAM & $0.02 \mu \mathrm{m}$ & $\pm 15 \%$ & $1 \mathrm{~Hz}$ \\
\hline $\begin{array}{l}\text { Particle-bound } \\
\text { polycyclic } \\
\text { aromatic hy- } \\
\text { drocarbons }\end{array}$ & $\begin{array}{l}\text { EcoChem PAS } 1000 \\
\text { photoelectric } \\
\text { aerosol sensor }\end{array}$ & UNAM & & & $0.3 \mathrm{~Hz}$ \\
\hline $\begin{array}{l}\text { Absorption co- } \\
\text { efficient }\end{array}$ & $\begin{array}{l}\text { Radiance research } \\
\text { particle soot } \\
\text { absorption } \\
\text { photometer (PSAP) }\end{array}$ & UNAM & $1 \mathrm{M} \mathrm{m}^{-1}$ & $\pm 25 \%$ & $1 \mathrm{~Hz}$ \\
\hline $\begin{array}{l}\text { Scattering } \\
\text { coefficient }\end{array}$ & $\begin{array}{l}\text { Radiance research } \\
\text { nephelometer }\end{array}$ & UNAM & $1 \mathrm{M} \mathrm{m}^{-1}$ & $\pm 25 \%$ & $1 \mathrm{~Hz}$ \\
\hline $\begin{array}{l}\text { Backscattering } \\
\text { vertical profile }\end{array}$ & $\begin{array}{l}\text { Vaisala ceilometer } \\
\text { CL-31 }\end{array}$ & UNAM & $\begin{array}{l}20 \mathrm{~m} \text { to } 7000 \mathrm{~m} \text {, } \\
\text { with } 20 \mathrm{~m} \\
\text { resolution }\end{array}$ & & $0.5 \mathrm{~Hz}$ \\
\hline
\end{tabular}

(Münkel and Räsänen, 2004) and is useful for measuring boundary layer height and structure (Münkel et al., 2007; van der Kamp and McKendry, 2010; Tsaknakis et al., 2011). Recently, a ceilometer network in Europe was used to track the plume from the eruption of the Eyjafjallajökull volcano (Flentje et al., 2010). As discussed below, the plume from the Puyehue volcano was obvious in the ceilometer measurements at our research site. Furthermore, we used the ceilometer profiles to compare with the AOT measured with MODIS and with the AERONET sun photometer (see Sect. 3). In order to carry out this comparison, we converted the nondimensional units of power recorded by the ceilometer to dimensions of extinction, as follows.

The extinction coefficient was derived from the sum of the in situ measurements of light scattering and absorption by the nephelometer and PSAP, respectively. As the ceilometer data does not provide a quantitative measure of the extinction coefficient, which is needed for the estimation of the AOT, we proceeded to correlate the in situ extinction coefficient and the ten-minute averages of the low level ceilometer data (between 20 and $60 \mathrm{~m}$ ) for selected periods when the boundary layer appeared well mixed up to at least $60 \mathrm{~m}$. The extinction coefficient derived from the in situ measurements is fit to the averaged backscattered power between $20-60 \mathrm{~m}$ with a linear regression constrained to pass through zero. As shown in Fig. 1, the amount of dispersion is sufficiently small to obtain a reasonable relationship between the backscattered power and extinction coefficient. The best-fit equation presented in the figure was used to convert the backscattered power from the ceilometer to the extinction coefficient:

$$
\mathrm{AOT}_{\text {ceilometer }}=\sum_{z=20 \mathrm{~m}}^{z=7000 \mathrm{~m}} 0.553 \cdot C_{i} \cdot \Delta Z
$$

where $\Delta Z=20 \mathrm{~m}$ and $C_{i}$ are the raw counts in the $i$ th channel of the ceilometer.

As Buenos Aires is a megacity with high levels of anthropogenic emissions (Alonso et al., 2010; D'Angiola et al., 2010), the influence of the particles in the volcanic plume has to be distinguished from the normal (background), daily trends in particle measurements. In order to do this, we calculated hourly, diurnal averages and standard deviations from 15 April 2011, when the measurements began, to 31 July 2011. We have combined the measurements made during all the days without volcanic influence: before the first episode, in between episodes and after the last episode, to estimate the background urban conditions. The different instruments acquire data at different frequencies, as listed in Table 2; therefore, ten-minute averages of the different variables were constructed to homogenize the dataset.

The diurnal variation of the typical urban conditions in Buenos Aires was determined in the manner described above, indistinct from the day of the week. This typical diurnal 


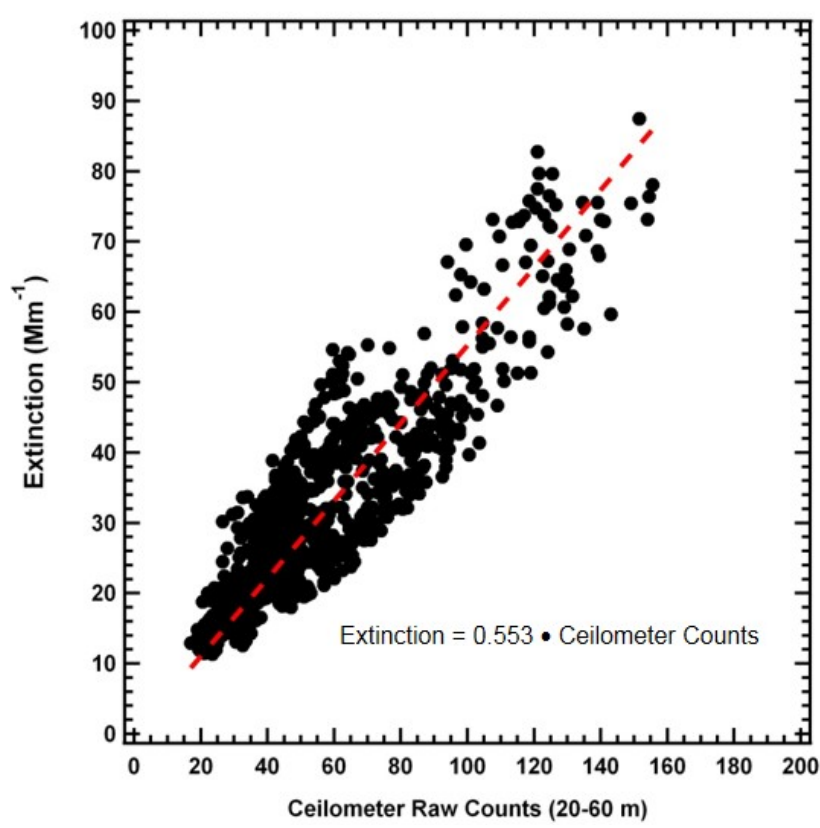

Fig. 1. Shown here is the extinction coefficient, derived from the nephelometer and PSAP measurements as a function of the raw backscattering, range-corrected counts from the ceilometer averaged between 20 and $60 \mathrm{~m}$. Each point represents a ten minute average.

evolution is characterized by the average of the different variables and their respective standard deviation. No distinction was made between working and weekend days, assuming that the variability between them is captured by the standard deviation. The ten-minute averages of the particle measurements during days with volcanic influence are then compared with the background average estimates of the diurnal evolution of the typical urban conditions, as described above.

Finally, to complement our measurements, we have analysed also the mass concentration of the coarse fraction of aerosol particles with aerodynamic diameter smaller than 10 micrometres $\left(\mathrm{PM}_{10}\right)$. The hourly $\mathrm{PM}_{10}$ mass concentrations are estimated using an automatic equipment (TEOM with $\mathrm{PM}_{10}$ inlet, THERMO Scientific) installed in an air quality monitoring station (Estacion Cordoba), funded by the city government of Buenos Aires. As the data were not available as text files, for the analysis the data were digitized from the graphs displayed on the web page of the city environmental agency (http://www.buenosaires.gob.ar/areas/med_ambiente/apra/ calidad_amb/red_monitoreo/index.php?menu_id=34232).

\section{Results}

Four case studies were identified in our dataset from 15 April to 31 July, when the volcanic plume affected Buenos Aires. The case studies were: 7 and 8 June (episode 1 on Table 1);
13 and 14 June (episode 3 on Table 1); 1 and 2 July (episode 5 on Table 1); and 7 and 8 July (episode 6 on Table 1). For brevity, we present in this paper only one of the case studies in detail (1-2 July); all the other cases were analysed similarly. After the initial, more important eruption on 4 June, the vent continued to be active for many months. The period from 20 June up to 1 July (before the case study presented here) was characterized by continuous emissions only up to $4-5 \mathrm{~km}$ above the level of the crater rim. There was rain/snow at the location of the volcanic complex on several of the days during this period, which would have scavenged most of the large ash particles in the vicinity. However, during periods with no precipitation, gases and small particles would have been advected by the predominant winds. The synoptic situation in all four cases studied was analysed and consistently showed conditions in which the volcanic plume would have reached Buenos Aires.

\subsection{Synoptic description}

The synoptic situation in each of the four case studies identified, while somewhat different, explains how the volcanic plume travelled about $1400 \mathrm{~km}$ to reach Buenos Aires. On 1 July most of the country was under the influence of an extended high pressure system, with low level flow from the S-SW associated with a cold air incursion, clearly depicted by the 500/1000 hPa thickness field (Fig. 2a). While this situation persisted during the following day (Fig. 2b), it evolved near the volcano and led to a change in wind direction near the surface. At $850 \mathrm{hPa}$ southerly winds are observed over Patagonia and SW winds over Buenos Aires on 1 July (Fig. 3a), again leading to a change in direction by 2 July (Fig. 3b), which probably transported the newly released material towards Chile and the Pacific. Higher up in the atmosphere ( $700 \mathrm{hPa}$, not shown) the winds advected the volcanic plume over Buenos Aires, but at $500 \mathrm{hPa}$ the winds were from the $\mathrm{W}$.

\subsection{Meteorology and particle measurements}

Figure 4 presents time series (in local time LT) of the different observed parameters for the period 1-2 July (Julian days 182 and 183, respectively, corresponding to the fifth plume episode over Buenos Aires, listed in Table 1). The bottom panel (Fig. 4a) presents the vertical profile of aerosol light extinction derived from the ceilometer backscattering measurements using the relationship discussed in Sect. 2.2 and it is shown twice to facilitate relating it with the other parameters. The other panels present a black solid line with vertical bars that correspond to the average values and standard deviations, estimated from all the days when there was no volcanic influence detected. The green lines correspond to the 10 min average observations for 1 and 2 July.

Note that on 1 July there is a very inhomogeneous yet thick aerosol layer extending at times up to $3000 \mathrm{~m}$ (Fig. 4a) 

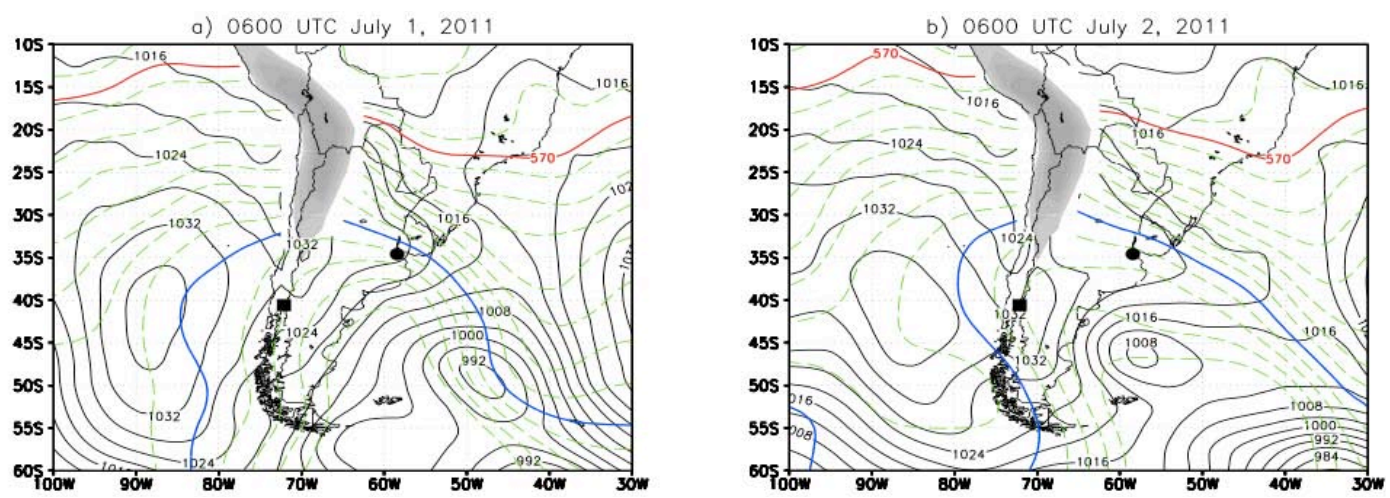

Fig. 2. Sea level pressure (in hPa, black contours) and 500/1000 thickness fields (in dam, green dotted contours) for 06:00 UTC on (a) 1 July 2011 and (b) 2 July 2011. The blue line corresponds to 540 dam and the red line to 570 dam. The square indicates the location of the Puyehue volcano and the dot corresponds to the location of Buenos Aires. Terrain elevations greater than $1500 \mathrm{~m}$ are shaded.
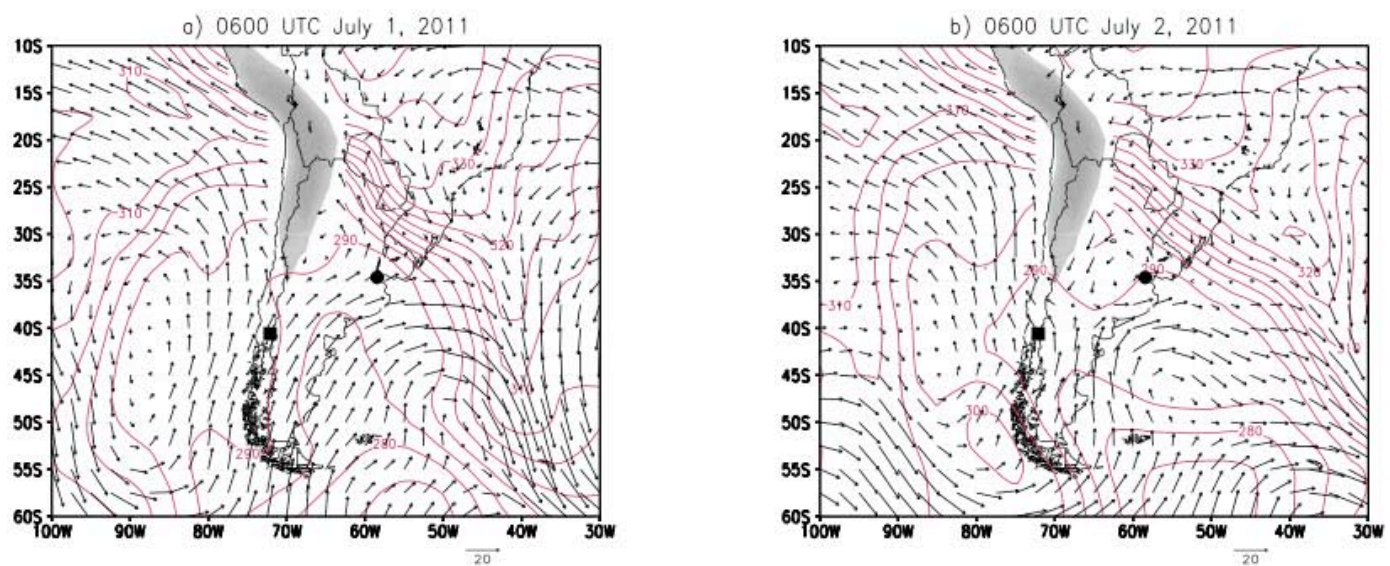

Fig. 3. $850 \mathrm{hPa}$ horizontal wind (in $\mathrm{m} \mathrm{s}^{-1}$, vectors) and equivalent adiabatic potential temperature (in $\mathrm{K}$, contours) for 06:00 UTC on (a) 1 July 2011 and (b) 2 July 2011. The square indicates the location of the Puyehue volcano and the dot corresponds to the location of Buenos Aires. Terrain elevations greater than $1500 \mathrm{~m}$ are shaded.

and showing undulations throughout the two-day period suggesting that the volcanic plume was likely meandering over the area. The period from 18:00 LT on 1 July, lasting until 08:00 on 2 July, shows lower concentration of aerosols and a subsiding air mass where we can see the volcanic layer descending, associated with increasing light extinction. At this time the local wind velocity is close to zero (Fig. 4h) inhibiting any dispersal of the falling volcanic particles. Calm conditions are consistent with the meteorological situation described above. As Buenos Aires is under the influence of a high pressure system, the low level flow is characterized by light winds and variable directions. The filament of ash merges into the boundary layer at 10:00 at which time there is a significant increase in the extinction coefficient throughout the mixed layer up to an altitude of about $1000 \mathrm{~m}$. This likely represents not only the volcanic plume that is descending from an upper layer but possibly the incursion of a lower level plume arriving from farther away.
The time series of CN (Fig. 4b), PPAH (Fig. 4c) and absorption coefficient (Fig. 4d) in this 2 day period all show values above one standard deviation, related to the presence of the volcanic plume in the boundary layer. In the mornings of each day, all three of these particle parameters exceeded the background averages by almost a factor of four, and in the afternoons they were greater than factors of two to three. The hourly $\mathrm{PM}_{10}$ mass concentrations (Fig. 4e), show an increase around 13:00 LT and almost constant values during the remaining hours in this 2 day period. The values are a factor of two or three greater than the background average considered in this study.

The ambient temperature on both days was almost $4{ }^{\circ} \mathrm{C}$ lower than the background average, well below one standard deviation, and the humidity was also much lower than the background average. While this may be partially an artefact due to the fact that the background averaging period happens during the transition of fall to winter, there appears to be a spatial coherency between the near surface temperature 

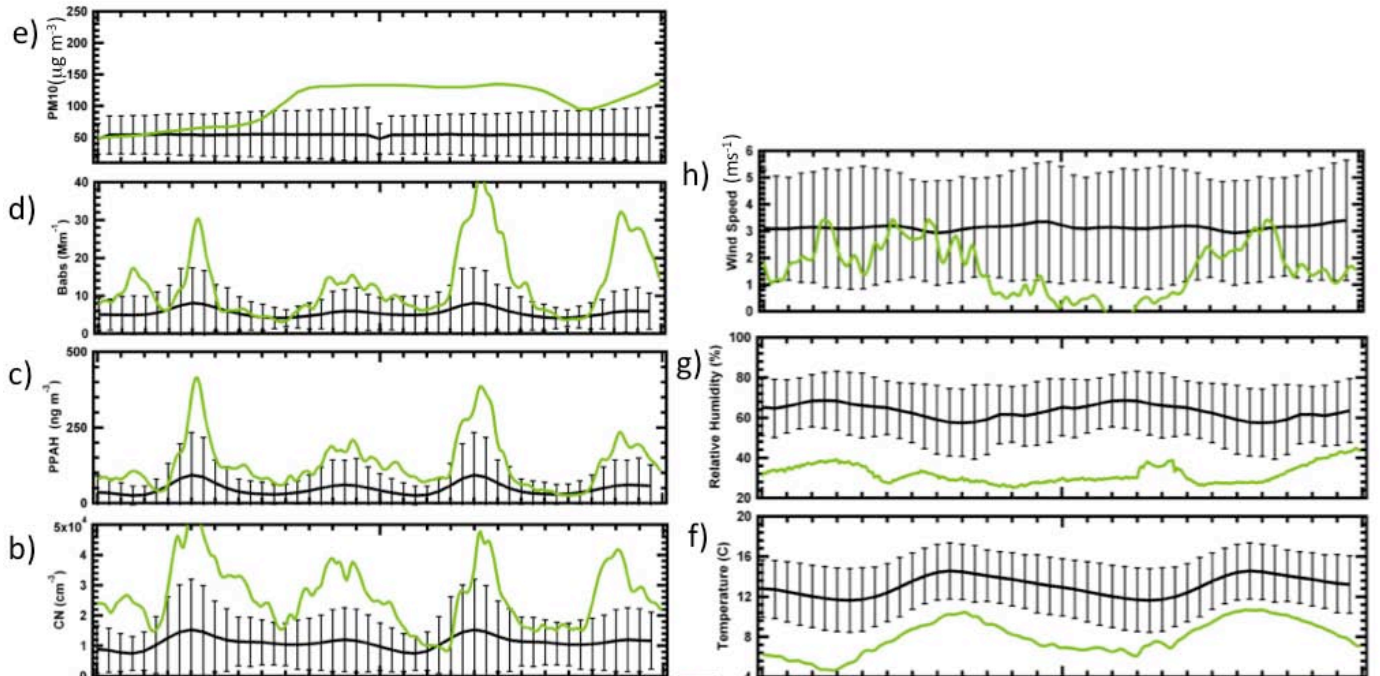

a)
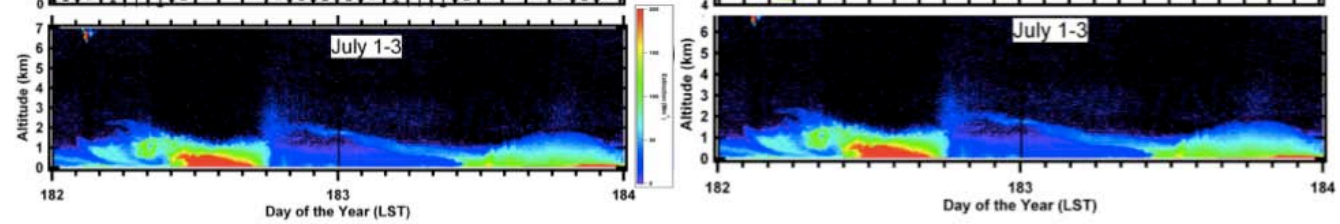

Fig. 4. Time series for the period 1-2 July, 2011 showing (a) the vertical profile of aerosol extinction (in $\mathrm{M} \mathrm{m}^{-1}$, red indicates the highest values), (b) CN concentration, (c) PPAH concentration, (d) absorption coefficient, (e) $\mathrm{PM}_{10}$, (f) temperature, (g) relative humidity and (h) wind velocity. The black solid lines are the daily average background from days with no volcanic ash and the vertical bars are one standard deviation. The green lines show the ten-minute averages observed those days. The tick marks in the horizontal axes correspond to $2 \mathrm{~h}$.

(from NCEP Reanalysis-2) and the spatial distribution of AOT observed by MODIS (on Terra and Aqua, for more description, see Sect. 3.4) for the period 1-2 July, as can be seen in Fig. 5. The panels in this figure show a noteworthy overall spatial coherence; nevertheless, they do not necessarily imply cause and effect. Okazaki and Heki (2012) analysed temperature anomalies at the $250 \mathrm{hPa}$ level for the 2010 Icelandic and 2011 Chilean cases, but did not present any measurements at the surface. Their results did not indicate a temperature decrease observed after the 2011 Chilean case, which is not consistent with our results. Their study showed a bias observed in the NCEP reanalysis dataset at $250 \mathrm{hPa}$ before the eruption and as they state in their study, it is possible that this may have affected their estimates of temperature after the eruption.

\subsection{Analysis of all days under volcanic influence}

Frequency distributions were derived for the observations of all days with volcanic influence and compared with the corresponding distributions for all days without such influence. Figure 6 presents the frequency distributions of the average background concentration (black line) and for the 8 days ( 7 , 8,13 and 14 June and 1, 2, 7 and 8 July) when volcanic influence was detected (red line), for the $\mathrm{CN}$ concentration (Fig. 6a), the absorption coefficient (Fig. 6b), the $\mathrm{PM}_{10}$ concentration (Fig. 6c) and the PPAH concentration (Fig. 6d).
Note that for all parameters, the distributions present much higher frequencies for large values corresponding to the days with volcanic influence over Buenos Aires. It is clear that the observations of those 8 days are not typical of urban pollution and represent enhanced conditions due to the volcanic ash plume present over the city.

Another evidence of non-typical urban conditions can be derived from the dispersion diagrams for pairs of variables, such as is presented in Fig. 7. The correlation between PPAH and $\mathrm{CN}$ is shown in Fig. 7a, where the black dots correspond to the average background pollution and the red dots show the observed values during the volcanic influence over the city. Note that for average background conditions the correlation is quite good between these 2 variables, indicative of common sources or formation processes in the atmosphere from precursor gases. In contrast, the measurements show much less correlation during the 8 days with the volcanic influence. The same behaviour is observed in Fig. 7b, for the correlation between $\mathrm{CN}$ and the aerosol absorption coefficient. Very little correlation is seen, suggesting that the processes that give rise to the very small particles and their optical properties are likely very different.

\subsection{Aerosol optical thickness}

Given the usefulness of satellites for providing images and optical depth measurements that can be used to track and 

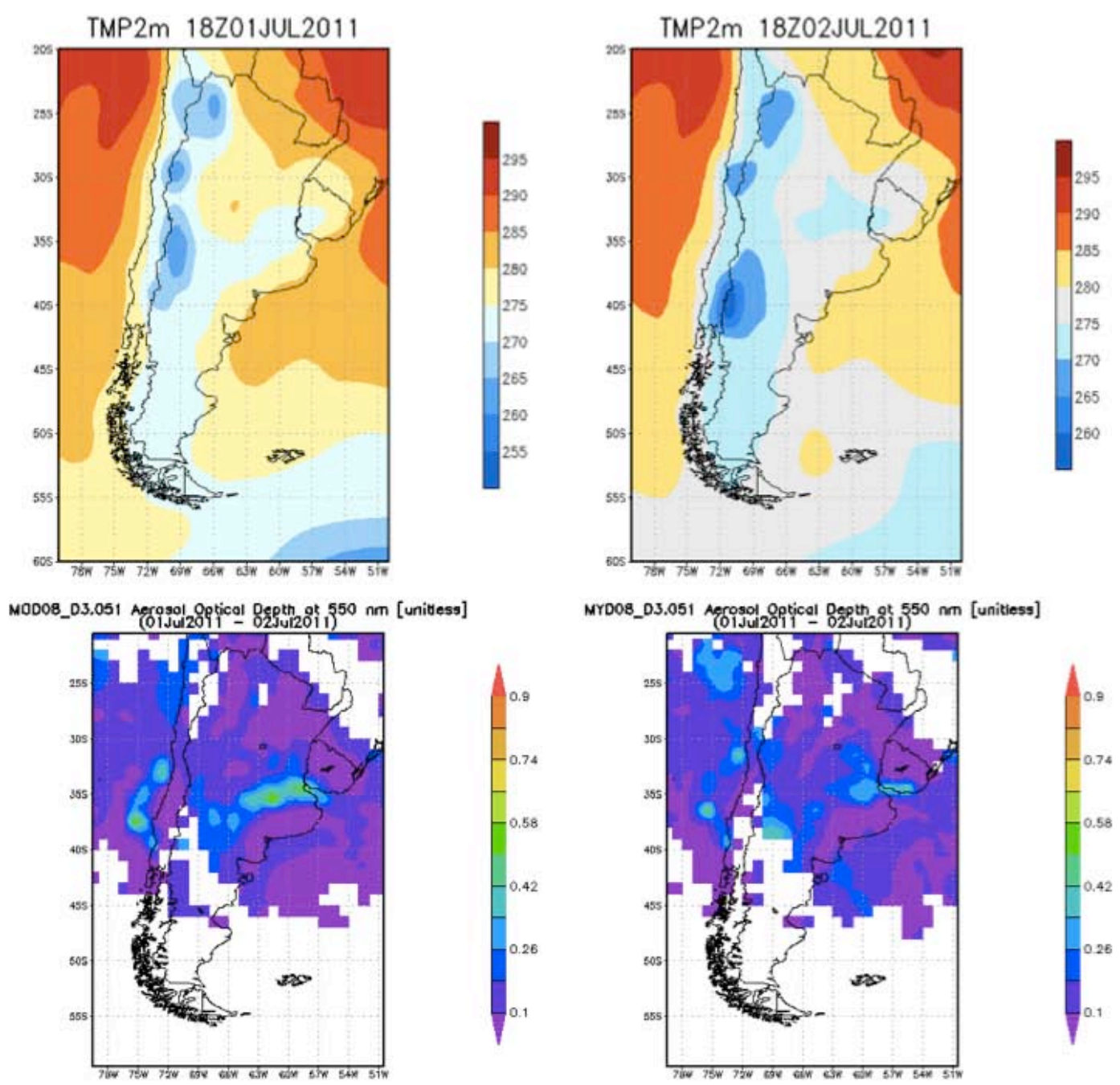

Fig. 5. Spatial distribution of the near surface temperature $(\mathrm{K})$ at $18 \mathrm{Z}$ for 1 and 2 July 2011 (top panels). Spatial distribution of Aerosol Optical Thickness derived from MODIS for 1-2 July 2011, from Terra (bottom left panel) and Aqua (bottom right panel).

possibly estimate the atmospheric loading of the volcanic ash (such as is presented in Fig. 5), we evaluated the AOT derived from the measurements with the MODIS sensor that is mounted on the Aqua and Terra satellites. The AOT from MODIS is provided at a wavelength of $550 \mathrm{~nm}$ and the Terra and Aqua satellites make overpasses of the Buenos Aires region every day at approximately 14:00 and 18:00 UTC (11:00 and 15:00 LT), respectively. While satellite observations provide valuable information on regional and global scales, ground-based measurements are representative of only small areas. However, it should be noted that aerosol measurements from space might have errors in the derived aerosol products in areas where the surface reflectance is high. The AERONET sun photometer measurements during this same period, using the $500 \mathrm{~nm}$ channel, were also included in the evaluation because they are considered as the "ground truth" for satellite product validation (Levy et al., 2010). As described in Sect. 2.2, we estimate the extinction coefficient at $550 \mathrm{~nm}$ from the raw, range-corrected ceilometer backscatter measurements and subsequently derive the AOT.

The two airports in Buenos Aires were closed on a number of occasions due to the threat of volcanic ash to aircraft as discussed in the introduction. These days are listed in Table 1, along with our assessment of the presence of volcanic ash from the ceilometer profiles. We have chosen the days in this table to compare the AOTs from the two satellites with those from the ceilometer and the AERONET sun photometer. The ceilometer and AERONET AOTs were averaged over one hour intervals before and after each of the satellite overpasses to provide a single value from each to compare with the satellite data.

Figure 8 summarizes these comparisons for the volcanic episodes over Buenos Aires during the months of June and July, where the black, green, red and blue bars represent the AOT from MODIS-Aqua, MODIS-Terra, the ceilometer 

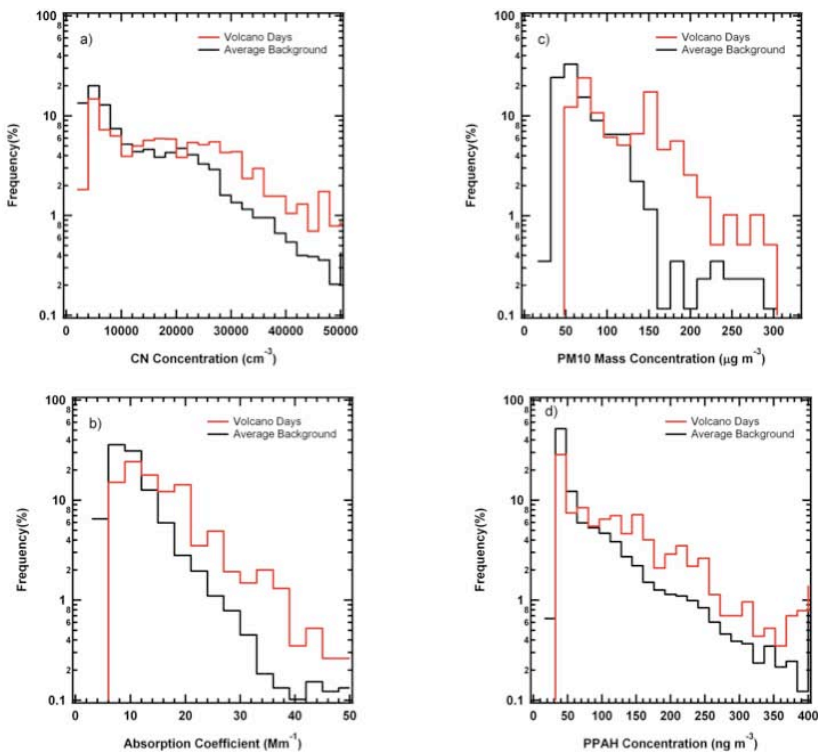

Fig. 6. Frequency distribution of the average background concentration (black line) and for the 8 days when volcanic influence was detected (red line), for: (a) CN concentration, (b) absorption coefficient, (c) $\mathrm{PM}_{10}$ and (d) PPAH concentration.

and AERONET, respectively. The standard deviations around the means were calculated over the averaging interval from the ceilometer and the AERONET and are shown as vertical bars. The uncertainty in the MODIS values was estimated from the number of pixels that were used to compute the AOT from these data. The vertical bars on the Aqua and Terra measurements were calculated as

$\sigma=(\sqrt{ } N / N) \mathrm{AOT}$

where $N$ is the number of pixels.

A large amount of variation is observed in this figure. Sometimes all four estimates of the AOT are in very good agreement, e.g. days 183 and 188, while on other days 2 out of the 4 estimates of AOT might be in close agreement while the other 2 could be significantly larger or smaller. No systematic order is apparent between the different estimates and probably reflects the inhomogeneity of the aerosols in the atmospheric column, in general, and the large variability in the location of the volcanic plume, in particular. One of the contributing factors to the large variation is the difference in the volume of atmosphere sampled. The MODIS has a footprint of $10 \mathrm{~km} \times 10 \mathrm{~km}$, whereas the ceilometer and AERONET sun photometer, with very small viewing angles, sample a narrow column of air.

The figure also shows colored blocks along the top axis that represent how the decision of the authorities to shut down airport operations (or airlines to cancel flights) matched what the ceilometer indicated about the presence of volcanic ash in the region. A red block shows that there were no flights when the ceilometer also indicated a volcanic
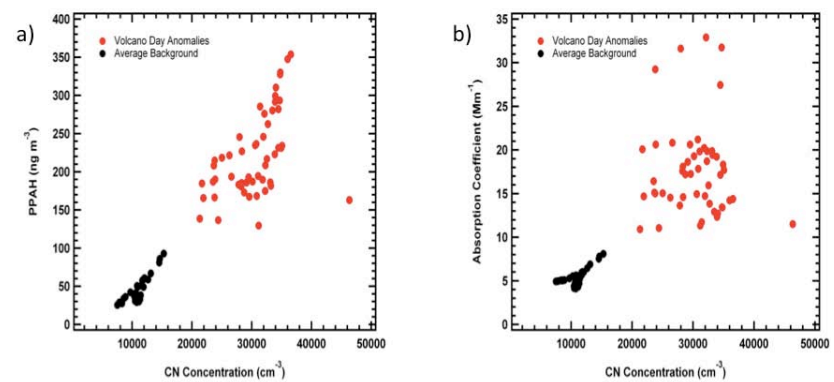

Fig. 7. Correlation between (a) $\mathrm{PPAH}$ and $\mathrm{CN}$ concentrations and (b) absorption coefficient and $\mathrm{CN}$ concentrations, for the average background day (black dots) and days when the volcanic influence was detected (red dots).

plume, an orange block shows that there were flights but that the ceilometer possibly detected a volcanic plume in the vicinity of the airport and the green block is the case of no flights when the ceilometer also indicated no volcanic plume above it.

\section{Discussion}

The synoptic situations observed during all the episodes of the volcanic plume affecting Buenos Aires explain the advection of the plume from its emission point about $1400 \mathrm{~km} \mathrm{SW}$ of the city. The plume was injected at an altitude of around $10 \mathrm{~km}$ above the level of the crater rim on the initial eruption (but only reaching lower altitudes in subsequent eruptions) and, during its transit, it underwent vertical settling and was subjected to synoptic scale descending motions. Eventually, the plume reached the top of the city's boundary layer and was entrained and mixed with near-surface air, resulting in ash deposition at the surface. The descent rate observed was too rapid to be the result of particle sedimentation so dynamic forcing must have been responsible for the subsidence. In fact, the synoptic maps all showed that Buenos Aires was always under a high-pressure system of varying magnitude, with its associated subsidence, when the ash was present (e.g. Fig. 2). The vertical profiles of aerosol backscatter indicated that the ash layer was already mixing downward by the time it reached the measurement site. Although the evidence is not decisive, some of the thermodynamic profiles analyzed (but not shown here) suggest that the volcanic particles absorbed solar radiation, transferred the heat to the local environment and raised the temperature within the layer producing small inversions at the level of the observed plume. The presence of these mainly hygroscopic volcanic particles also caused the drying of the atmospheric layer. Furthermore, the presence of the volcanic plume appears to have lowered the temperature and relative humidity at the surface (as seen in Fig. $4 \mathrm{f}$ and g).

The measurements of particle characteristics at the surface allowed us to determine the natural variability of the urban emissions under many synoptic conditions before the 


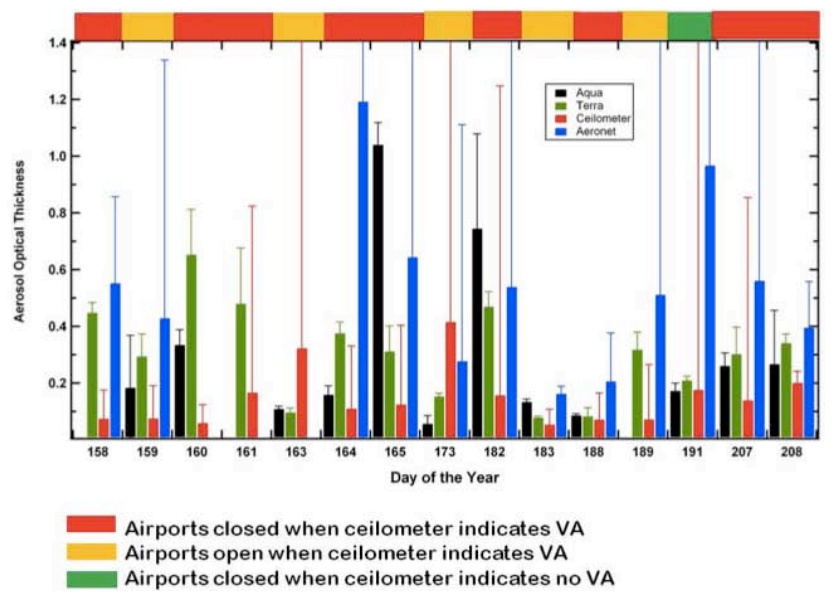

Fig. 8. The aerosol optical thickness (AOT) is shown here from the MODIS instrument on the Aqua (black) and Terra (green) satellites and derived from the ceilometer (red) and AERONET (blue). The ceilometer and AERONET AOT are averages made over the time periods of Aqua and Terra overpasses. The vertical bars represent the uncertainties, derived for the satellite measurements from the number of pixels from which the AOT was derived, and the computed standard deviations from the averaged values of ceilometer and AERONET. The days shown are taken from Table 1 and the color-coding indicates how the ceilometer identified volcanic ash compared with the decision to close an airport. VA corresponds to volcanic ash.

volcanic ash arrived in Buenos Aires. Our results indicate that all of the aerosol properties at the surface were elevated with respect to the background average when the ash layer was identified overhead, in most instances observations are more than one standard deviation above the average background, and showed enhancements of factors of 2 to 4 above the background average.

The enhanced $\mathrm{CN}$ concentration observed was likely related to the formation of new particles within the plume as it was being advected away from the source, similar to what was found by Schäfer et al. (2011). When this type of volcano erupts, it will emit not only ash but also a variety of gases, including water vapor and sulfidric acid $\left(\mathrm{SH}_{2}\right)$ and sulfur dioxide $\left(\mathrm{SO}_{2}\right)$ (Andres and Rose, 1995). The conversion of $\mathrm{SO}_{2}$ to sulfate particles in the presence of water vapor has been well documented in other cases (e.g. for the Popocatepetl volcano in Mexico City; Raga et al., 1999; Jimenez et al., 2004) and may explain the observed local increases of very small particles at the surface. These small particles would be inefficiently removed by the sedimenting larger particles.

The increase in the polycyclic aromatic hydrocarbons (PAHs) determined in the particles by our instrumentation is more puzzling, since clearly PAHs are not emitted by the volcanic source. This increase had to be the result of the interaction of the normal urban emissions with the particles in the volcanic plume. At this point, we can only hypothesize that perhaps gaseous PAH were adsorbed onto the particles in the volcanic plume or that chemical reactions were occurring at the surface of these particles resulting in an increased concentration of PPAH.

The increase in the signal of the absorption coefficient must be related to the composition of the particles in the volcanic plume. Under normal urban conditions, the measurement of absorption coefficient is directly linked to primary black carbon (BC) from combustion sources. The particles in the volcanic plume may have contained some metals that would also absorb light at a wavelength of $550 \mathrm{~nm}$. The newly formed particles from the gas-to-particle conversion that appeared as enhanced $\mathrm{CN}$ concentrations, may have also contributed to this enhanced absorption signal. Another possible explanation would be that the volcanic particles descending from the elevated plume were scavenging the urban $\mathrm{BC}$ particles, mixed throughout the boundary layer, resulting in an enhanced absorption coefficient measured at the surface by our measurement system.

The analysis of the frequency distributions shows that during days influenced by volcanic ash, all parameters are much higher than for days that correspond to average background pollution in Buenos Aires. Moreover, the observations presented in Fig. 6 suggest that the parameters in the days influenced by the volcanic ash are not part of the same distribution associated with the typical urban pollution.

Furthermore, dispersion diagrams between the observed variables (Fig. 7) indicate that the nature of the processes that relate them is very different during average background urban pollution and during those days with volcanic influence. Variables that in an urban setting would be correlated (e.g. $\mathrm{CN}$ and absorption coefficient, associated with emissions from diesel vehicles such as buses) are not correlated at all during the days with volcanic influence.

An attempt at a quantitative comparison of all the different estimates of AOT (from satellite and ground-based) suggests that it is a very difficult task to accomplish (Fig. 8). Estimates from MODIS on Terra and Aqua correspond to "instantaneous" measurements at two different times of the day and they varied from $50 \%$ to factors of 2 for the same day. This would be indicative of the transient nature of the plume over the selected area. Differences between AOT values determined at the AERONET site (located about $4 \mathrm{~km}$ from our research site) and our estimate from the ceilometer would indicate spatial variability of the plume and in most cases the ceilometer values were smaller than AERONET ones. The largest estimate from AERONET was 1.2 on 13 June, while the largest value from MODIS-Aqua was 1.05 on 14 June, suggesting that the bulk of the plume arrived after the overpass of Aqua on 13 June. AERONET values were usually higher than the other three estimates. 


\section{Summary and conclusions}

A suite of instruments deployed on the roof of one of the buildings of the FCEN, UBA, initially installed to make urban pollution measurements, was used to detect and characterize several intrusions of volcanic ash that affected the city during June and July 2011.

We have presented here a variety of remote and in situ measurements and the synoptic conditions prevalent during one of the case studies when both airports in Buenos Aires were closed to air traffic due to the presence of an ash cloud. While not presented here for brevity, all the other case studies showed similar results. The measurements by remote sensing and corresponding analysis allow us to make the following conclusions:

- The ceilometer clearly identified the volcanic plume aloft and the measurements showed the descent of the plume into the boundary layer.

- Quantitative AOT estimates are possible from the ceilometer measurements based on an algorithm relating the raw backscatter with the extinction derived from in situ measurements under well-mixed conditions in the boundary layer.

- The estimates of AOT derived from AERONET, ceilometer and MODIS, indicate that all three platforms were able to identify the volcanic ash plume simultaneously.

- Quantitative comparison of the different estimates of AOT is difficult, suggesting large spatial and temporal variability of the plume.

- AOT estimates by the ceilometer are smaller than those from AERONET.

The analysis of the in situ measurements during the periods when volcanic ash was present over the research site leads to the following conclusions:

- All the particle measurements increased beyond the average background by at least one standard deviation, demonstrating the sensitivity of the instruments to identify the plume signature at the surface.

- The anomalous concentrations of $\mathrm{CN}$ suggest new particle formation, presumably from the conversion of $\mathrm{SO}_{2}$.

- The anomalous concentrations of PPAH may come from the uptake of PAHs on the plume particles or from chemical reactions on the surface of plume particles.

- The anomalous absorption coefficients indicate that plume particles may contain certain compounds that can absorb radiation at $550 \mathrm{~nm}$. Another possible explanation consistent with the observations is the scavenging of black carbon from urban sources as the plume descends through the boundary layer to the surface.

- The presence of the ash layer may have led to a decrease in temperature and relative humidity at the surface.

Acknowledgements. This research was partially funded by projects UBACyT X224 and 20020100101013 and ANPCyT PICT 08-1739 in Argentina. Universidad Nacional Autónoma de México (UNAM) is gratefully acknowledged for covering the costs of transportation of the equipment from Mexico City to Buenos Aires. Partial funding was also provided by grant Conacyt-Semarnat 23498 in Mexico. The National Weather Service of Argentina provided the upper air soundings and we thank G. Santamaria for providing the Journal Lima Victor. The authors would like to thank the NASA Goddard Space Flight Center DAAC and MODIS software development and support teams and B. Holben and the AERONET PIs for collecting the aerosol observations around the world. NCEP is acknowledged for the meteorological data.

The Air Quality Monitoring Network of the city of Buenos Aires is acknowledged for the $\mathrm{PM}_{10}$ measurements. SERNAGEOMIN from Chile is gratefully acknowledged for providing the daily reports that describe the eruptive process.

Finally, the authors are grateful to the staff of the Facultad de Ciencias Exactas y Naturales, Universidad de Buenos Aires (FCEN, UBA) for their invaluable help and logistic support during the measurement campaign.

Edited by: A. Costa

\section{References}

Alonso, M. F., Longo, K. M., Freitas, S. R., Mello da Fonseca, R., Marécal, V., Pirre, M., and Gallardo Klenner, L.: An urban emissions inventory for South America and its application in numerical modeling of atmospheric chemical composition at local and regional scales, Atmos. Environ., 44, 5072-5083, 2010.

Andres, R. J. and Rose, W. I.: Remote sensing spectroscopy of volcanic plumes and clouds, in: Monitoring Active Volcanoes, edited by: McGuire, B., Kilburn, C. R. J., and Murray, J., UCL Press, 310-314, 1995.

Bukowiecki, N., Zieger, P., Weingartner, E., Jurányi, Z., Gysel, M., Neininger, B., Schneider, B., Hueglin, C., Ulrich, A., Wichser, A., Henne, S., Brunner, D., Kaegi, R., Schwikowski, M., Tobler, L., Wienhold, F. G., Engel, I., Buchmann, B., Peter, T., and Baltensperger, U.: Ground-based and airborne in-situ measurements of the Eyjafjallajökull volcanic aerosol plume in Switzerland in spring 2010, Atmos. Chem. Phys., 11, 10011-10030, doi:10.5194/acp-11-10011-2011, 2011.

Collini, E., Osores, M. S., Folch, A., Viramonte, J. G., Villarosa, G., and Salmuni, G.: Volcanic ash forecast during the June 2011 Cordon Caulle eruption, Nat Hazards, 66, 389-412, doi:10.1007/s11069-012-0492-y, 2013. 
D’Angiola, A., Dawidowski, L. E., Gómez Darío, R., and Osses, M.: On-road traffic emissions in a megacity, Atmos. Environ., 44, 483-493, 2010.

Flentje, H., Claude, H., Elste, T., Gilge, S., Köhler, U., PlassDülmer, C., Steinbrecht, W., Thomas, W., Werner, A., and Fricke, W.: The Eyjafjallajökull eruption in April 2010 - detection of volcanic plume using in-situ measurements, ozone sondes and lidar-ceilometer profiles, Atmos. Chem. Phys., 10, 10085-10092, doi:10.5194/acp-10-10085-2010, 2010.

Folch, A., Costa, A., and Macedonio, G.: FALL3D: a computational model for volcanic ash transport and deposition, Comput. Geosci., 35, 1334-1342, 2009.

Gerlach, D. C., Frey, F. A., Moreno-Roa, H., and Lopez-Escobar, L.: Recent volcanism in the Puyehue-Cordón Caulle region, southern Andes, Chile $\left(40.5^{\circ} \mathrm{S}\right)$ : Petrogenesis of evolved lavas, J. Petrol., 29, 333-382, 1988.

Hervo, M., Quennehen, B., Kristiansen, N. I., Boulon, J., Stohl, A., Fréville, P., Pichon, J.-M., Picard, D., Labazuy, P., Gouhier, M., Roger, J.-C., Colomb, A., Schwarzenboeck, A., and Sellegri, K.: Physical and optical properties of 2010 Eyjafjallajökull volcanic eruption aerosol: ground-based, Lidar and airborne measurements in France, Atmos. Chem. Phys., 12, 17211736, doi:10.5194/acp-12-1721-2012, 2012.

Holben, B. N., Eck, T. F., Slutsker, I., Tanré, D., Buis, J. P., Setzer, A., Vermote, E., Reagan, J. A., Kaufman, Y., Nakajima, T., Lavenu, F., Jankowiak, I., and Smirnov, A.: AERONET - A federated instrument network and data archive for aerosol characterization, Remote Sens. Environ., 66, 1-16, 1998.

Jimenez, J. C., Raga, G. B., Baumgardner, D., Castro, T., Rosas, I., Báez, A., and Morton, O.: On the Composition of Airborne Particles Influenced by Emissions of the Volcano Popocatépetl in Mexico, Nat. Hazards, 31, 21-37, 2004.

Kalnay, E., Kanamitsu, M., Kistler, R., Collins, W., Deaven, L., Gandin, L., Iredell, M., Saha, S., Woolen, J., Zhu, Y., Chelliah, M., Ebizuzaki, W., Higgins, W., Janowiak, J., Mo, K., Ropelevski, C., Wang, J., Leetmaa, A., Reynolds, R., Roy, J., and Dennis, J.: The NCEP/NCAR 40-year reanalysis project, B. Am. Meteorol. Soc., 77, 437-471, 1996.

Lara, L. E., Moreno-Roa, H., and Naranjo, J. A.: Rhyodacitic fissure eruption in Southern Andes (Cordón Caulle; $40.5^{\circ} \mathrm{S}$ ) after the 1960 (Mw:9.5) Chilean earthquake: A structural interpretation, J. Volcanol. Geoth. Res., 138, 127-138, doi:10.1016/j.jvolgeores.2004.06.009, 2004.

Lara, L. E., Moreno-Roa, H., Naranjo, J. A., Matthews, S., and Pérez de Arce, C.: Magmatic evolution of the Puyehue-Cordón Caulle volcanic complex $\left(40^{\circ} \mathrm{S}\right)$, southern volcanic zone: From shield to unusual rhyolitic fissure volcanism, J. Volcanol. Geoth. Res., 157, 343-366, doi:10.1016/j.jvolgeores.2006.04.010, 2006.

Levy, R. C., Remer, L. A., Kleidman, R. G., Mattoo, S., Ichoku, C., Kahn, R., and Eck, T. F.: Global evaluation of the Collection 5 MODIS dark-target aerosol products over land, Atmos. Chem. Phys., 10, 10399-10420, doi:10.5194/acp-10-10399-2010, 2010.
Münkel, C. and Räsänen, J.: New optical concept for commercial lidar ceilometers scanning the boundary layer, Proc. SPIE, 5571, 364, doi:10.1117/12.565540, 2004.

Münkel, C., Eresmaa, N., Räsänen, J., and Karppinen, A.: Retrieval of mixing height and dust concentration with lidar ceilometer, Bound.-Lay. Meteorol., 124, 117-128, 2007.

Okazaki, I. and Heki, K.: Atmospheric temperature changes by volcanic eruptions: GPS radio occultation observations in the 2010 Icelandic and 2011 Chilean cases, J. Volcanol. Geoth. Res., 245246, 123-127, 2012.

Parkinson, C. L.: Aqua: An Earth-observing satellite mission to examine water and other climate variables, IEEE T. Geosci. Remote, 41, 173-183, 2003.

Pitz, M., Gu, J., Soentgen, J., Peters, A., and Cyrys, J.: Particle size distribution factor as an indicator for the impact of the Eyjafjallajökull ash plume at ground level in Augsburg, Germany, Atmos. Chem. Phys., 11, 9367-9374, doi:10.5194/acp-11-93672011, 2011.

Raga, G. B., Kok, G. L., Baumgardner, D., Rosas, I., and Baez, A.: Evidence for volcanic influence on Mexico City aerosols, Geophys. Res. Lett., 26, 1149-1152, 1999.

Schäfer, K., Thomas, W., Peters, A., Ries, L., Obleitner, F., Schnelle-Kreis, J., Birmili, W., Diemer, J., Fricke, W., Junkermann, W., Pitz, M., Emeis, S., Forkel, R., Suppan, P., Flentje, H., Gilge, S., Wichmann, H. E., Meinhardt, F., Zimmermann, R., Weinhold, K., Soentgen, J., Münkel, C., Freuer, C., and Cyrys, J.: Influences of the 2010 Eyjafjallajökull volcanic plume on air quality in the northern Alpine region, Atmos. Chem. Phys., 11, 8555-8575, doi:10.5194/acp-11-8555-2011, 2011.

SERNAGEOMIN: Reporte Especial de Actividad Volcánica No. 28, Región de Los Ríos, Complejo Volcánico Puyehue Cordón Caulle, available from the authors on request, 2011.

Singer, B. S., Jicha, B. R., Harper, M. A., Naranjo, J. A., Lara, L. E., and Moreno-Roa, H.: Eruptive history, geochronology, and magmatic evolution of the Puyehue-Cordón Caulle volcanic complex, Chile, Geol. Soc. Am. Bull., 120, 599-618, doi:10.1130/B26276.1, 2008.

Tsaknakis, G., Papayannis, A., Kokkalis, P., Amiridis, V., Kambezidis, H. D., Mamouri, R. E., Georgoussis, G., and Avdikos, G.: Inter-comparison of lidar and ceilometer retrievals for aerosol and Planetary Boundary Layer profiling over Athens, Greece, Atmos. Meas. Tech., 4, 1261-1273, doi:10.5194/amt-4-1261-2011, 2011.

van der Kamp, D. and McKendry, I.: Diurnal and Seasonal Trends in Convective Mixed-Layer Heights Estimated from Two Years of Continuous Ceilometer Observations in Vancouver, BC, Bound.Lay. Meteorol., 137, 459-475, 2010. 